\title{
APLIKASI MOBILE VOTING BERBASIS ANDROID UNTUK PEMILIHAN KETUA OSIS DENGAN MODEL RAD STUDI KASUS SMAN 1 PARUNGKUDA
}

\author{
A. Gunawan', Ramdhan Saepul Rohman², Andika Purnama ${ }^{3}$, Gunawan ${ }^{4}$, \\ ${ }_{1}^{1}$ AMIK BSI Sukabumi \\ e-mail: agunawan.agn@bsi.ac.id \\ 2 AMIK BSI Sukabumi \\ e-mail: ramdhan.rpe@bsi.ac.id \\ ${ }^{3}$ AMIK BSI Sukabumi \\ e-mail: andika@gmail.com \\ ${ }^{4}$ AMIK BSI Sukabumi \\ e-mail: gunawan.gnz@bsi.ac.id
}

\begin{abstract}
Abstrak
Penggunaan voting sebagai media dalam membuat keputusan yang berkaitan dengan hajat hidup orang banyak telah dimulai sejak lama. Voting merupakan kegiatan yang sangat menentukan pada setiap perhelatan pemilihan, banyak varian kepentingan yang harus diakomodir di dalamnya, bagaimana regulasi atau peraturan yang disepakati dan menjadi aturan main, siapa yang dipilih dan siapa yang berhak memilih. SMA Negeri 1 Parungkuda selama ini dalam menentukan pemilihan ketua osis menggunakan metode voting (pemungutan suara) secara konvensional yaitu dengan cara semua siswa pada setiap kelasnya diberikan lembar yang berisi nama calon-calon yang dimajukan sebagai calon ketua osis, kemudian siswa akan menceklis nomor salah satu dari calon tersebut. RAD merupakan perangkat lunak yang menekankan siklus perkembangan dalam waktu yang singkat. RAD menggunakan metode berulang dalam mengembangkan sistem dimana model bekerja sistem dikonstruksikan di awal tahap pengembangan dengan tujuan menetapkan kebutuhan pengguna. Dalam penulisan skripsi ini di terapkan teknologi mobile voting berbasis android dengan model RAD untuk pemilian ketua osis pada SMA Negeri 1 Parungkuda.
\end{abstract}

Kata Kunci: Voting, Mobile Voting, RAD, SMAN 1 Parung kuda

\section{Pendahuluan}

Android merupakan sebuah sistem operasi perangkat mobile berbasis linux yang mencakup sistem operasi, Middleware dan aplikasi.[1] Penerapan pada android aplikasi Mobile memungkinkan user melakukan mobilitas dengan menggunakan perlengkapan seperti PDA, telepon seluler atau Handphone.[2]

Voting adalah kegiatan yang sangat menentukan pada setiap perhelatan pemilihan, banyak varian kepentingan yang harus diakomodir di dalamnya, bagaimana regulasi atau peraturan yang disepakati dan menjadi aturan main, siapa yang dipilih dan siapa yang berhak memilih. Voting lebih mengacu pada proses pemanfaatan perangkat elektronik untuk lebih mendukung kelancaran proses dan juga model otomatisasi yang memungkinkan campur tangan minimal dari individu dalam semua prosesnya.[3]

\section{Metode Pengembangan Aplikasi}

Metode yang digunakan untuk Mobile Voting berbasis Mobile ini menggunakan metode RAD. [4] Penggunaan Metode ini memiliki 3 tahapan yaitu :

1) Rencana Kebutuhan

User dan analyst melakukan pertemuan untuk mengidentifikasi tujuan dari sistem dan kebutuhan informasi untuk mencapai tujuan. Pada tahap ini merupakan hal terpenting yaitu adanya keterlibatan dari kedua belah pihak. 
2) Proses desain sistem

Pada tahap ini keaktifan user yang terlibat menentukan untuk mencapai tujuan karena pada proses ini melakukan proses desain dan melakukan perbaikan-perbaikan apabila masih terdapat ketidaksesuaian desain antara user dan analyst. Seorang user dapat langsung memberikan komentar apabila terdapat ketidaksesuaian pada desain, merancang sistem dengan mengacu pada dokumentasi kebutuhan user yang dibuat pada tahap sebelumnya. Keluaran dari tahapan ini adalah spesifikasi software yang meliputi organisasi sistem secara umum, struktur data dan yang lain.

\section{3) Implementasi}

Tahapan ini adalahan tahapan programmer yang mengembangkan desain suatu program yang telah disetujui oleh user dan analyst. Sebelum diaplikasikan pada suatu organisasi terlebih dahulu dilakukan proses pengujian terhadap program tersebut apakah ada kesalahan atau tidak. Pada tahap ini user biasa memberikan tanggapan akan sistem yang sudah dibuat serta mendapat persetujuan mengenai sistem tersebut.

Tabel 1 Kebutuhan Perangkat Keras

\begin{tabular}{|l|l|}
\hline \multicolumn{2}{|c|}{ Jenis perangkat keras } \\
\hline Personal Computer & \multicolumn{1}{|c|}{ Smartphone } \\
\hline $\begin{array}{l}\text { Intel(R) Celeron(R) } \\
\text { CPU N330 @1.10 } \\
\text { GHz }\end{array}$ & $\begin{array}{l}\text { Operation System } \\
\text { OS Android 7.1.2 } \\
\text { Naugat }\end{array}$ \\
\hline HDD 500GB & Memory 16 Gb \\
\hline RAM 2 Gb & RAM 2 Gb \\
\hline Monitor & Kabel Data \\
\hline
\end{tabular}

\section{Hasil dan Pembahasan}

a. Aplikasi Voting

Aplikasi Voting berbasis Mobile dianggap lebih mudah dan lebih efisien dikarenakan semua prosesnya sudah dilakukan oleh Handphone dan Komputer. Aplikasi ini juga membantu pengguna untuk lebih mudah memilih dan menentukan calon yang akan di pilih. Aplikasi Voting juga mempermudah dalam proses penghitungan suara, karena dilakukan secara online, suara hasil pemilihan yang masuk bisa langsung diketahui tanpa harus menghitung kertas suara seperti proses pemilihan secara manual. [5]

\section{b. Aplikasi Mobile}

Aplikasi Mobile merupakan sebuah aplikasi yang memungkinkan Anda melakukan mobilitas dengan menggunakan perlengkapan seperti PDA, telepon seluler atau Handphone. Dengan menggunakan aplikasi mobile, Anda dapat dengan mudah melakukan berbagai macam aktifitas mulai dari hiburan, berjualan, belajar, mengerjakan pekerjaan kantor, browsing dan lain sebagainya. Pemanfaatan aplikasi mobile untuk hiburan paling banyak digemari oleh hampir $70 \%$ pengguna telepon seluler, karena dengan memanfaatkan adanya fitur game, music player, sampai video player membuat kita menjadi semakin mudah menikmati hiburan kapan saja dan dimanapun. [6]

c. RAD (Rapid Aplication Development)

Rapid Aplication Development (RAD) sebuah proses perkembangan perangkat lunak sekuensial linier yang menekankan siklus perkembangan dalam waktu yang singkat. RAD menggunakan metode iteratif (berulang) dalam mengembangkan sistem dimana working model (model bekerja) sistem dikonstruksikan di awal tahap pengembangan dengan tujuan menetapkan kebutuhan (requirement) pengguna dan selanjutnya disingkirkan. Dalam pengembangan sistem informasi normal, memerlukan waktu minimal 180 hari, namun dengan menggunakan metode RAD, sistem dapat diselesaikan dalam waktu 30-90 hari. [7]

\section{d. Appypie}

Appy Pie merupakan salah satu online builder yang tersedia di internet. Appy Pie ini dapat mendukung proses pembuatan aplikasi berbasis Android, Mac OS, Windows Phone, Blackberry, dan HTML 5. Appy pie adalah suatu website yang menyediakan template dalam pembuatan aplikasi android secara gratis dan berbayar. Dalam pembuatan dengan appy pie harus terkoneksi langsung dengan internet yaitu secara online. [8]

\section{e. Metode Algoritma}

Algoritma Naïve Bayes yaitu algoritma yang memanfaatkan pencarian nilai probabilitas tertinggi untuk proses klasifikasi pada data uji yang tepat. Pada penelitian menggunakan data uji berupa data Voting mengenai pemilihan kepala 
daerah Jakarta dimana setiap pasangan calon memiliki 100 data Voting positif dan 100 data Voting negatif. Banyak ditemukan penelitian yang menggunakan metode Algoritma Naïve Bayes pada analisa sentimen, hal ini karena Naïve Bayes memiliki kelebihan melakukan proses klasifikasi yang sederhana tetapi cukup tinggi performa akurasinya. Selain itu, metode Naïve Bayes juga memiliki kekurangan yaitu sangat sensitif terhadap pemilihan fitur sehingga jika terlalu banyak jumlah fitur kemungkinan akan mengurangi nilai akurasi klasifikasi[9].

\section{F. Uji Coba}

Uji coba sistem dalam pembuatan program aplikasi mobile voting pemilihan ketua osis di SMAN 1 Parungkuda di lakukan dengan pengetesan logika yang telah di berikan pada masing masing tombol untuk mengetahui apakah masih ada kesalahan atau tidak. Dengan menjalankan program dapat di ketahui mana yang tidak sesuai dengan fungsinya. Apabila ada kesalahan akan muncul di block editor ketika ada kesalahan yang tidak benar.

Tabel 2. Pengujian Aplikasi

\begin{tabular}{|l|l|l|c|}
\hline $\begin{array}{c}\text { Data } \\
\text { Masukan }\end{array}$ & $\begin{array}{l}\text { Yang } \\
\text { Diharap } \\
\text { kan }\end{array}$ & $\begin{array}{l}\text { Pengama } \\
\text { tan }\end{array}$ & $\begin{array}{c}\text { Kesimpu } \\
\text { lan }\end{array}$ \\
\hline $\begin{array}{l}\text { Klik ikon } \\
\text { Calon } \\
\text { ke } 1\end{array}$ & $\begin{array}{l}\text { Akan } \\
\text { muncul } \\
\text { Profil } \\
\text { calon ke } \\
1\end{array}$ & $\begin{array}{l}\text { Akan } \\
\text { keluar Visi } \\
\text { Misi calon } \\
\text { ke 1 }\end{array}$ & Sesuai \\
\hline $\begin{array}{l}\text { Klik ikon } \\
\text { Calon } \\
\text { ke } 2\end{array}$ & $\begin{array}{l}\text { Akan } \\
\text { muncul } \\
\text { Profil } \\
\text { calon ke }\end{array}$ & $\begin{array}{l}\text { Akan } \\
\text { keluar visi } \\
\text { Visi calon } \\
\text { ke 2 }\end{array}$ & Sesuai \\
\hline $\begin{array}{l}\text { Klik foto } \\
\text { SMAN 1 } \\
\text { parungk } \\
\text { uda }\end{array}$ & $\begin{array}{l}\text { Akan } \\
\text { muncul } \\
\text { Profil }\end{array}$ & $\begin{array}{l}\text { Keluar } \\
\text { sejarah } \\
\text { dan visi } \\
\text { misi } \\
\text { sekolah }\end{array}$ & Sesuai \\
\hline $\begin{array}{l}\text { Klik ikon } \\
\text { Voting } \\
\text { calon }\end{array}$ & $\begin{array}{l}\text { Muncul } \\
\text { kedua } \\
\text { Foto } \\
\text { calon }\end{array}$ & $\begin{array}{l}\text { Keluar } \\
\text { kedua } \\
\text { foto calon }\end{array}$ & Sesuai \\
\hline
\end{tabular}

Use case diagram menggambarkan fungsional sistem atau persyaratanpersyaratan yang harus dipenuhi sistem dari pandangan pemakai, dapat dilihat pada gambar 1.

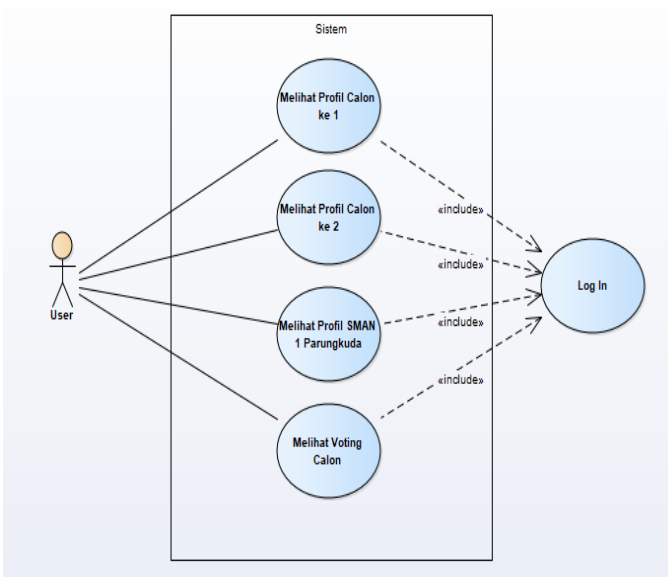

Gambar 1. Use Case Diagram

Activity Diagram menggambarkan aktivitas yang dilakukan oleh sistem bukan aktivitas yang dilakukan oleh pengguna, activity diagram halaman voting dapat dilihat pada gambar 1.

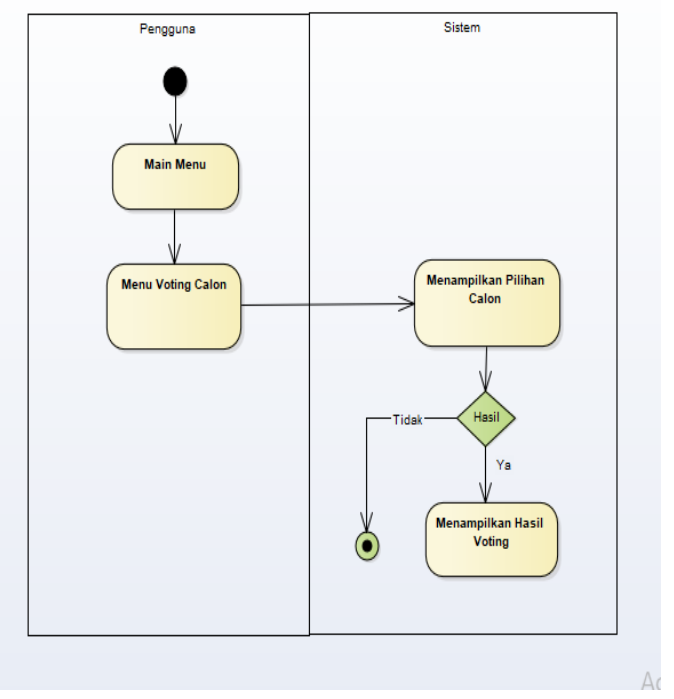

Gambar 2. Activity Diagram Halaman Voting

Sequence diagram menggambarkan kelakuan objek pada use case dengan mendeskripsikan waktu hidup objek dan pesan yang dikirim dan diterima antara objek, dapat dilihat pada gambar 3 . 


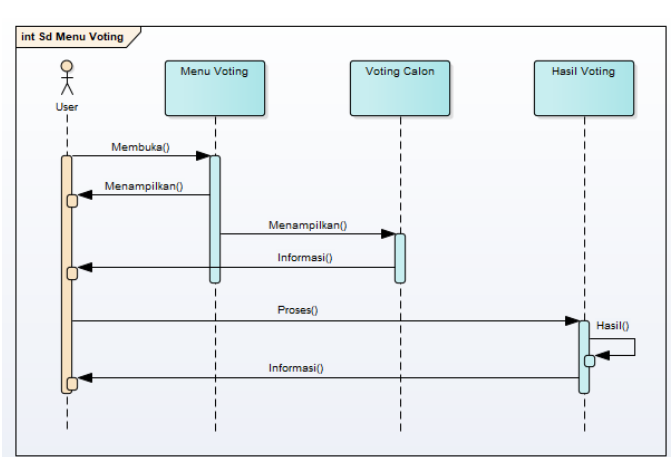

Gambar 3. Sequence Diagram Halaman Voting

Perancangan user interface akan di tampilkan pada saat program di jalankan hingga menampilkan output. Gambar 4 menunjukan rancangan user interface halaman voting pada aplikasi voting.

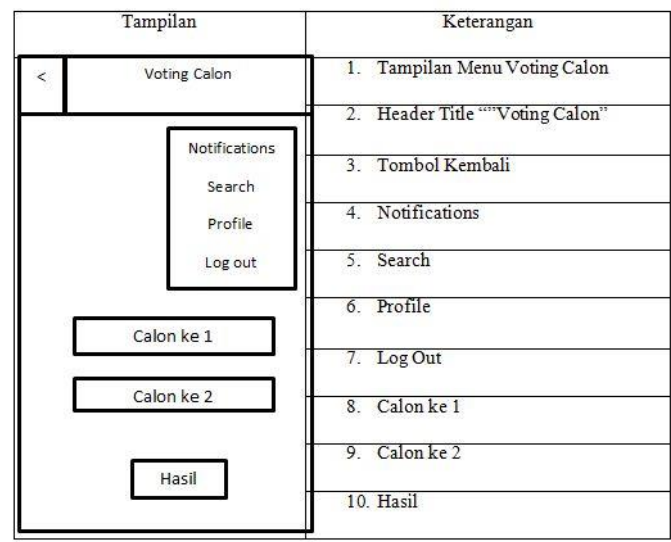

Gambar 4. User Interface Halaman Voting

\section{Kesimpulan}

Melalui Aplikasi ini dapat mempermudah bagi pihak Sekolah dalam penginputan data, pengolahan data, Penentuan Ketua Osis serta penyimpanan data-data yang ada, dapat membantu dalam menyampaikan tentang Penentuan Ketua Osis agar lebih, cepat, hemat waktu, hemat biaya serta tepat dalam pengambilan keputusan. Sehingga menghasilkan sistem yang tepat, cepat, akurat dan transparan.

\section{Referensi}

[1] Murtiwiyati; and G. Lauren, "Rancang Bangun Aplikasi Pembelajaran Budaya Indonesia Untuk Anak Sekolah Dasar berbasis Android," J. IIm. KOMPUTASI, vol. 12, p. 2,3, 2013.

[2] R. Farizah, Nur and Kosidin, "Pemodelan aplikasi mobile reminder berbasis android," Semin. Nas. Teknol. Inf. dan Komunikas, vol. 2016, no. Sentika, pp. 18-19, 2016.

[3] R. A. Adhi, "Rancang Bangun Sistem Informasi E-Voting Berbasis SMS ( Developing E-Voting Information System SMS Based)," Juita, vol. III, no. 2, pp. 85-93, 2014.

[4] S. Aswati and Y. Siagian, "Model Rapid Application Development Dalam Rancang Bangun Sistem Informasi Pemasaran Rumah ( Studi Kasus: Perum Perumnas Cabang Medan," Sesindo, pp. 317-324, 2016.

[5] I. dkk Agustina, "Berbasis Android," Development, pp. 14-20, 2016.

[6] W. C. Indhiarta, "Penggunaan NGram Pada Analisa Sentimen," 2017.

[7] Aswati, S., \& Siagian, Y. (2016). Model Rapid Application Development Dalam Rancang Bangun Sistem Informasi Pemasaran Rumah ( Studi Kasus: Perum Perumnas Cabang Medan. Sesindo, 317-324.

[8] Agustina, I. dkk. (2016). Berbasis Android. Development, 14-20.

[9] Indhiarta, W. C. (2017). Penggunaan N-Gram Pada Analisa Sentimen. 